\title{
Reproductive and vegetative behavior of hybrid jabuticaba tree under flowering induction ${ }^{1}$
}

\author{
Carlos Kosera Neto ${ }^{2}$, Alexandre Hack Porto ${ }^{2}$, \\ Marciéli da Silva ${ }^{2}$, Juliana Cristina Radaelli², Américo Wagner Júnior ${ }^{2}$
}

\section{ABSTRACT}

Brazil is one of the countries with the greatest vegetal diversity in the world, especially for the Myrtaceae family, to which the jabuticaba tree belongs. Its fruits are of great acceptability, but it is little explored commercially, because it takes a long time to reach the production stage. This study aimed to evaluate the vegetative and reproductive behavior of hybrid jabuticaba trees under flowering induction treatments. A randomized block design was used, with the following treatments: calcium carbide, etefon, paclobutrazol, daily irrigation management and control. Growth and reproductive development data were evaluated. For vegetative growth, there was no difference among the treatments, demonstrating no negative effect. On the other hand, paclobutrazol showed to be the most promising treatment, because it anticipates flowering, is effective in induction and results in a higher production.

KEYWORDS: Plinia spp.; Myrtaceae; paclobutrazol.

\section{INTRODUCTION}

Brazil has one of the largest vegetal diversities in the world (Amaral \& Fierro 2013), as well as huge native fruit trees with genetic heterogeneity, particularly in the southern region, where the Myrtaceae family includes many fruit producing species that are exotic and unknown to a large part of the population.

Fruits of this species have dark colors and variations in smell and flavor, standing out those of the jabuticaba tree (Plinia spp.) as a non-traditional tropical fruit (Rufino et al. 2010). This species is distributed all over the country, from the Pará to the Rio Grande do Sul state, but the main production states are São Paulo, Rio de Janeiro, Minas Gerais and Espírito Santo (Franco et al. 2010). In the southwest of the Paraná state, specifically in the Araucaria

\section{RESUMO}

Comportamento vegetativo e reprodutivo de jabuticabeira híbrida sob indução de florescimento

O Brasil é um dos países com a maior diversidade vegetal do mundo, com destaque para a família Myrtaceae, à qual pertence a jabuticabeira. Seus frutos são de grande aceitabilidade, mas é pouco explorada comercialmente, pois demora a entrar em produção. Objetivou-se avaliar o comportamento vegetativo e reprodutivo de jabuticabeira híbrida submetida a tratamentos de indução de florescimento. Adotou-se delineamento em blocos casualizados, com os seguintes tratamentos: carbureto de cálcio, etefon, paclobutrazol, manejo diário de irrigação e controle. Foram avaliados os dados de crescimento e desenvolvimento reprodutivo. Para crescimento vegetativo, não houve diferença entre os tratamentos, demonstrando não haver efeito negativo. Já o paclobutrazol mostrou-se o mais promissor, por antecipar o florescimento, ser efetivo na indução e apresentar maior produção.

PALAVRAS-CHAVE: Plinia spp.; Myrtaceae; paclobutrazol.

forest ecosystem, jabuticaba trees occur naturally (Danner et al. 2010).

The jabuticaba species $P$. trunciflora (DC) Berg, P. cauliflora (DC) Berg. and P.jaboticaba (Vell) are already well-known (Mattos 1983), but some of the commercialized plants are named as 'Híbrida' and classified as P. cauliflora (Lorenzi et al. 2006). These plants show desirable characteristics such as a smaller size, reduced juvenile period, fruits with excellent organoleptic qualities and the potential to fruit up to five times a year, depending on climatic conditions and management (Kinupp et al. 2011).

Jabuticaba fruits are considered very acceptable by consumers due to their sensorial characteristics, and they show a great potential (Vernier \& Cardoso 2013) for commercialization and consumption. There is a number of interesting biochemical elements found in these fruits, such as anthocyanin, phenolic acid, 
flavonoids, salicylic acid, ellagic acid, gallic acid, gallocatechin and antioxidants, which help to protect humans against free radicals and prevent cancer (Vieira \& Ferreira 2013, Lage et al. 2014, Lucena et al. 2014). However, despite these positive qualities, there has not been extensive commercial exploration of this fruit in orchards, as most fruits are obtained by extractive activity (Malagi et al. 2012). The absence of information about commercial management suggests an inadequate production, thus generating a negative multiplier factor. Therefore, to increase cultivation, research on species domestication is crucial (Salla et al. 2015), particularly regarding flowering induction techniques.

The main blossoming of the southern jabuticaba native plant occurs between August and November, with fruit ripening up to December, but flowering also occurs in January or February, with fruit ripening up to April (Vieira \& Ferreira 2013), showing a concentrated production in a short period. Due to the multiple flowering periods, flowering control is necessary to provide the off-season fruit production, establish production and commercialization logistics, attract commercial interest and enable an increase in the fruits price.

To achieve these goals, some techniques may be used to avoid the need for climatic conditions. For example, growing controls (bioregulators) are successfully used to enhance production (Sridharan et al. 2015) or induce flowering and increase the productivity of other species (Upreti et al. 2014). Bioregulators are a kind of synthetic chemical compost used in agriculture to modify morphological and physiological characteristics and to promote or suppress vegetative development (Leite \& Crusciol 2008). In woody angiosperms, the use of bioregulators directly influences the vegetative and reproductive growth, since some of them block the gibberellin biosynthesis, a hormone that promotes cell stretching and meristem division (Moraes et al. 2014), while other bioregulators are ethylene precursors (Cunha 2005).

The bioregulators that are most common and well understood are calcium carbide (Brescasin et al. 2013), ethephon (Cunha 2005, Schmidt et al. 2009, Moraes et al. 2012) and paclobutrazol (Cavatte et al. 2012, Moraes et al. 2012, Oliveira et al. 2012, Moraes et al. 2014). These chemicals are largely used to promote flowering in mango trees (Mangifera indica) (Cardoso et al. 2007, Akram et al. 2013), apple trees (Malus domestica) (Schimidt et al. 2009), grapevines (Vitis sp.) (Costa et al. 2016), olive trees (Olea europaea) (Fernandez-Escobar et al. 1992, Oliveira et al. 2012), banana trees (Musa sp.) (Cavatte et al. 2012), acid lime trees (Citrus latifolia Tanaka cv. 'Tahiti') (Cruz et al. 2009), pineapple (Ananas comosus) (Maruthasalan et al. 2010, Kist et al. 2011) and other ornamental species (Moraes et al. 2012, Brescasin et al. 2013). Despite the good results obtained with these other species, these products are not used in native fruits yet, especially in jabuticaba tree.

It has been empirically observed that flowering occurs after pruning or continuous irrigation. Therefore, if bioregulators are correctly used, this may provide a longer period to fruit harvest, allowing the establishment of commercialization strategies, such as producing fruits off-season (Kist et al. 2011), when the prices may reach higher values (Ataíde et al. 2006). Given all that, this study aimed to evaluate the vegetative and reproductive behavior of hybrid jabuticaba tree under flowering induction in orchards.

\section{MATERIAL AND METHODS}

The research was developed at the Universidade Tecnológica Federal do Paraná, in Dois Vizinhos (25 $41^{\prime} 49.47^{\prime \prime} S$ and $\left.53^{\circ} 5^{\prime} 41.46^{\prime \prime} \mathrm{W}\right)$, Paraná state, Brazil, from January to November 2014. During the experimental period, the temperature and average rainfall data were collected from a weather station located $300 \mathrm{~m}$ from the experimental site.

All plants were bought at a local store and were approximately four years old (adult-juvenile transition ontogeny age), with an average height of $1.20 \mathrm{~m}$. They were put into plastic pots (25 L capacity) with MecPlant ${ }^{\circledR}$ commercial substrate and subjected to a drip irrigation system providing approximately $2 \mathrm{~L}_{\text {of water plant }}{ }^{-1}$ week $^{-1}$.

A randomized block experimental design was adopted, with eight replications of three plants each, totaling 120 plants. The treatments used were calcium carbide, ethephon and paclobutrazol, daily watering and control. The products were applied at two different times, the first in January and the second in March.

As an ethephon source, $100 \mathrm{~mL}$ of Ethrel $^{\circledR}$ solution ( $0.4 \mathrm{mg} \mathrm{L}^{-1}$ of a.i. indicated to mango tree) were sprayed all over the tree (trunk, branches and leaves). Paclobutrazol was applied in a liquid solution 
at a rate of $0.8 \mathrm{~g}$ of a.i. per tree proportion (indicated to mango tree) on the soil, close to the trunk. Calcium carbide was applied in a solid form ( $2 \mathrm{~g}$ per tree), inside a plastic hood (made with plastic bottles), followed by watering to provide hydrolysis and acetylene release. A watering can with a sieve was used for daily watering treatments, which always occurred in the afternoon ( $2 \mathrm{~L}$ of water per day per tree). Watering was not applied when it rained.

The tree height, trunk diameter, sprout length, number of leaves, epidermis renewal, flowering, number of flowers per tree and monthly flowering were evaluated.

To measure the vegetative growth, the tree height was evaluated with a measuring tape, and the trunk diameter was measured with calipers, using the difference between the measurements taken before the application, after the application and at the end of the trial. The number of sprouts and leaves were counted and differentiated by reddish coloration, and the shoot length was measured with a graded ruler. On each plant, 20 shoots with dormant buds were randomly selected and followed to total development. The epidermal renewal was visually evaluated by the detachment of the epidermal tissue from the trunk and branches, and was represented as the monthly percentage of plants that presented this characteristic.

Regarding the reproductive behavior, the number of days that elapsed between the application of the products and the appearance of the first reproductive structures was determined. The percentage of plants with reproductive structures, number of structures per plant and production were also evaluated. At 118 days after the product application, the data were collected for these variables when the first floral structures were observed, and data collection continued monthly until the end of the experiment.

The Pearson's correlation was applied for all variables, including climatic data, to evaluate their relationship. All data were submitted to the Lilliefors normality test. For the number of leaves, no changes were required; plant height, trunk diameter and epidermal detachment data were transformed by arc sen $\sqrt{x} / 100$; data on monthly and annual sprouts, shoot length and the percentage of plants with flowers were transformed by $\log (\mathrm{x}+1)$; and the number of reproductive structures was transformed according to $\sqrt{ } \mathrm{x}+1$. These transformations were necessary to adapt the data to the residual normal distribution assumption. Subsequently, the data were subjected to variance analysis and the means were compared by the Duncan test $(\alpha \leq 0.05)$, performed with the Sanest ${ }^{\circledR}$ software (Zonta \& Machado 1984).

\section{RESULTS AND DISCUSSION}

The vegetative growth behavior, which was analyzed by height and trunk diameter of the flowering-induced hybrid jabuticaba trees, did not show a significant difference with the bioregulator use, but the epidermal detachment presented contrasting values (Table 1).

The use of induction treatments on the hybrid jabuticaba trees did not affect the diameter growth in a negative or positive way. This result differed from other studies, in which ethephon had no effect on the Eucalyptus grandis growth, but paclobutrazol did (Moraes et al. 2012) on the Eucalyptus growth after 16 months (Moraes et al. 2014). When paclobutrazol is applied on the soil, its effects on growth can be observed over a longer period of time for some species (Oliveira et al. 2012), such as cherry trees (Prunus avium) (Facteau \& Chestnut 1991) and olive trees (Fernandez-Escobar et al. 1992). It may be that growth reduction takes place during later years, and this reduction may eventually occur in the jabuticaba tree as well, since its annual growth is slow.

The ethephon treatment provided a greater trunk and branch epidermal detachment, when compared to other inductors (Table 1). Ethephon is widely used in agriculture to release ethylene, which causes diverse alterations in cellular functions (Taiz \& Zeiger 2004). It is absorbed and translocated from all parts to the cells cytoplasm (Moraes et al. 2012), where it is degraded, releasing ethylene,

Table 1. Increase in trunk diameter, height and epidermal detachment of hybrid jabuticaba trees, after the application of flowering inducers (percentage values expressed).

\begin{tabular}{lccc}
\hline \multicolumn{1}{c}{ Inductor } & Diameter & Height & $\begin{array}{c}\text { Epidermal } \\
\text { detachment }\end{array}$ \\
\hline Paclobutrazol & $8.83^{\mathrm{ns}}$ & $4.08^{\mathrm{ns}}$ & $15.30 \mathrm{~b}^{*}$ \\
Ethephon & 12.01 & 5.31 & $52.38 \mathrm{a}$ \\
Control & 10.94 & 4.11 & $17.21 \mathrm{~b}$ \\
Watering & 11.79 & 5.77 & $23.56 \mathrm{~b}$ \\
Calcium carbide & 10.03 & 5.29 & $18.08 \mathrm{~b}$ \\
\hline CV $(\%)$ & 16.60 & 17.04 & 25.40 \\
\hline
\end{tabular}

* Averages followed by distinct letters differed by the Duncan's test $(\alpha \leq 0.05)$; ${ }^{\mathrm{n} s}$ not significant by the $\mathrm{F}$ test $(\mathrm{p} \leq 0.05)$. 
calcium chloride and phosphate ions (Cunha 2005). Considering that ethylene is a stress hormone, its impacts are unknown for species such as Plinia spp., but the data clearly shows an effect on the epidermal detachment from the trunk and branches.

The number of sprouts and leaves emitted during the growing season were not significantly different between the treatments (Table 2), showing that none of the treatments negatively affected the plant development, at least in the first cycle after the application. It was expected that paclobutrazol would inhibit the vegetative growth, as it acts on the gibberellin synthesis, a substance responsible for growth, as well as flowering inhibition (Mouco et al. 2010); however, this did not occur to the jabuticaba trees. Similar results were reported for apple trees, which did not express a significant difference between the paclobutrazol treatment and the control (Zhang et al. 2016).

Ethephon showed a statistical superiority for shoot length (Table 2). The highest development of sprouts was also observed on grapevines after the application of ethephon (Fracaro \& Pereira 2004). Ethylene has many functions, depending on the concentrations present (Almeida \& Rodrigues 2016), and reactions vary between plant species (Taiz \& Zaiger 2004). An example is irrigated rice (Oryza sativa), where an increase in the ethylene concentration results in a decrease in the level of endogenous abscisic acid, and this decrease is antagonistic to gibberellin, since the reduction of one implies the increase of the other (Kende \& Zeevaart 1997). Therefore, it is believed that ethephon provides the greatest shoot length due to the altered hormonal balance in hybrid jabuticaba tissues.

Table 2. Number of shoots, shoot length, annual number of shoots and number of leaves per shoot of hybrid jabuticaba trees, at 170 days after the application of the flowering inducing treatments.

\begin{tabular}{lcccc}
\hline \multicolumn{1}{c}{ Inductor } & Shoots & $\begin{array}{c}\text { Shoot } \\
\text { length }(\mathrm{cm})\end{array}$ & $\begin{array}{c}\text { Annual } \\
\text { shoots }\end{array}$ & Leaves \\
\hline Paclobutrazol & $83.85^{\mathrm{ns}}$ & $3.73 \mathrm{~b}^{*}$ & $438.38^{\mathrm{ns}}$ & $5.99^{\mathrm{ns}}$ \\
Ethephon & 86.17 & $4.34 \mathrm{a}$ & 456.31 & 6.15 \\
Control & 74.34 & $3.24 \mathrm{~b}$ & 380.69 & 5.41 \\
Watering & 80.48 & $3.43 \mathrm{~b}$ & 410.17 & 5.55 \\
Calcium carbide & 85.37 & $3.68 \mathrm{~b}$ & 439.90 & 5.82 \\
\hline CV $(\%)$ & 8.28 & 7.32 & 18.65 & 10.45 \\
\hline
\end{tabular}

* Averages followed by distinct letters differed by the Duncan's test $(\alpha \leq 0.05)$;

${ }^{n s}$ not significant by the F test $(\mathrm{p} \leq 0.05)$.
The most promising treatment for hybrid jabuticaba trees is paclobutrazol, because it presented much higher averages than other treatments, including the number of reproductive structures per plant, percentage of plants with flowering, number of fruits and blooming anticipation (Table 3).

The anticipation of a productive cycle is extremely important, since fruits supplied offseason provide better prices (Ataíde et al. 2006). Paclobutrazol promoted flower production at 131 days after induction, while the other treatments showed flowering 94 days later (Table 3). This difference is probably due to the inhibition of gibberellin biosynthesis, a hormone responsible for growth and antagonistic to flowering induction (Zhang et al. 2016). The use of triazol reduces plant growth and development (Kondhare et al. 2014, Zhang et al. 2016), and the carbohydrates produced that are not used for growth are redirected to flowering induction (Upreti et al. 2014).

Mango trees treated with paclobutrazol required little more than 80 days for visible flowering, but, in the control treatment, this was observed after 116 days (Yeshitela et al. 2004). Similarly to other species, the use of paclobutrazol on the hybrid jabuticaba trees anticipated flowering in 95 days, which was less than the number of days for visible flowering with the other treatments (Table 3).

Paclobutrazol induced monthly flowering in more than $65 \%$ of the jabuticaba trees, while the other treatments induced monthly flowering in only $4 \%$ of the trees. In addition, this treatment gave rise to a greater number of reproductive structures (73.38), while the other inductive treatments had less than two structures per plant. In mango trees (Cardoso

Table 3. Total number of reproductive structures (NRS), monthly flowering plants percentage (MFP), fruits produced (FP) and days required to flowering (DRF), after the application of flowering inducing treatments in hybrid jabuticaba trees.

\begin{tabular}{lcccc}
\hline \multicolumn{1}{c}{ Inductor } & NRS & MFP & FP & DRF \\
\hline Paclobutrazol & $73.38 \mathrm{a}^{*}$ & $65.63 \mathrm{a}^{*}$ & $15.08 \mathrm{a}^{*}$ & $131 \mathrm{a}^{*}$ \\
Ethephon & $1.86 \mathrm{~b}$ & $2.78 \mathrm{~b}$ & $0.31 \mathrm{~b}$ & $240 \mathrm{~b}$ \\
Control & $1.89 \mathrm{~b}$ & $3.29 \mathrm{~b}$ & $0.22 \mathrm{~b}$ & $226 \mathrm{~b}$ \\
Watering & $0.52 \mathrm{~b}$ & $2.45 \mathrm{~b}$ & $0.11 \mathrm{~b}$ & $225 \mathrm{~b}$ \\
Calcium carbide & $0.99 \mathrm{~b}$ & $1.46 \mathrm{~b}$ & $0.64 \mathrm{~b}$ & $249 \mathrm{~b}$ \\
\hline CV $(\%)$ & 39.76 & 61.57 & 42.51 & 13.25 \\
\hline
\end{tabular}

* Averages followed by distinct letters differed by the Duncan's test $(\alpha \leq 0.05)$. 
et al. 2007, Silva \& Neves 2011) and apple trees (Zhang et al. 2016), the same result was observed, where paclobutrazol presented a greater number of flowers. This occurs due to the decrease in the endogenous levels of gibberellins and the increase of cytokinins (Burondkar et al. 2016). The gibberellin synthesis inhibition is related to reproductive stage stimulation, resulting in early initiation of the floral buds (Moraes et al. 2014).

During four evaluation periods (191 to 248 days after the treatments application), more than $90 \%$ of the hybrid jabuticaba trees treated with paclobutrazol exhibited flowering, and $50-70 \%$ of the plants in the second and third evaluations showed flowers as well (Table 4).

Paclobutrazol treated plants showed higher amounts of starch in the leaves, as well as an increase in the soluble sugars such as sucrose, glucose and fructose in the buds, significantly influencing the carbohydrate balance in these tissues (Upreti et al. 2014), what may have also occurred with the hybrid jabuticaba trees and triggered them to flower.

All paclobutrazol treated jabuticaba trees had reproductive structures at 211 and 224 days after the product application (Table 4), while, with the other treatments, no more than $11 \%$ of the trees had reproductive structures. It was observed that paclobutrazol affects persistence for flowering stimulation, since the highest percentage of plants with reproductive structures occurs between 163 and 248 days, more specifically at 199 days after the product application (Figure 1). In other periods, higher values were always observed with paclobutrazol, when compared to the other treatments (Figure 1).

Table 4. Percentage of jabuticaba trees with the presence of reproductive structures, according to days after the treatment application (DAA) and flowering inducing treatment.

\begin{tabular}{|c|c|c|c|c|c|}
\hline DAA & Paclobutrazol & Ethephon & Control & Watering & Calcium carbide \\
\hline 118 & $6.96 \mathrm{dA}^{*}$ & $0.00 \mathrm{bA}$ & $1.58 \mathrm{aA}$ & $0.00 \mathrm{aA}$ & $1.58 \mathrm{aA}$ \\
\hline 141 & $47.65 \mathrm{bA}$ & $0.00 \mathrm{bB}$ & $1.58 \mathrm{aB}$ & $1.58 \mathrm{aB}$ & $1.58 \mathrm{aB}$ \\
\hline 163 & 73.20 abA & $5.30 \mathrm{abB}$ & $3.91 \mathrm{aB}$ & $6.96 \mathrm{aB}$ & $1.58 \mathrm{aB}$ \\
\hline 191 & $91.04 \mathrm{aA}$ & $5.30 \mathrm{abB}$ & $5.30 \mathrm{aB}$ & $3.91 \mathrm{aB}$ & $3.91 \mathrm{aB}$ \\
\hline 211 & $100.00 \mathrm{aA}$ & $5.30 \mathrm{abBC}$ & $10.76 \mathrm{aB}$ & $0.00 \mathrm{aC}$ & $1.58 \mathrm{aBC}$ \\
\hline 224 & $100.00 \mathrm{aA}$ & $8.72 \mathrm{abB}$ & $6.96 \mathrm{aB}$ & $5.30 \mathrm{aB}$ & $3.91 \mathrm{aB}$ \\
\hline 248 & $91.04 \mathrm{aA}$ & $2.62 \mathrm{abBC}$ & $10.76 \mathrm{aB}$ & $0.00 \mathrm{aC}$ & $3.91 \mathrm{aBC}$ \\
\hline 269 & $21.78 \mathrm{cA}$ & $2.62 \mathrm{abB}$ & $1.58 \mathrm{aB}$ & $0.00 \mathrm{aB}$ & $0.00 \mathrm{aB}$ \\
\hline 287 & 77.18 abA & $10.76 \mathrm{aB}$ & $3.91 \mathrm{aB}$ & $3.91 \mathrm{aB}$ & $1.58 \mathrm{aB}$ \\
\hline
\end{tabular}

* Averages followed by distinct letters, lowercase in the column and uppercase in the row, differed by the Duncan's test ( $\alpha \leq 0.05)$.

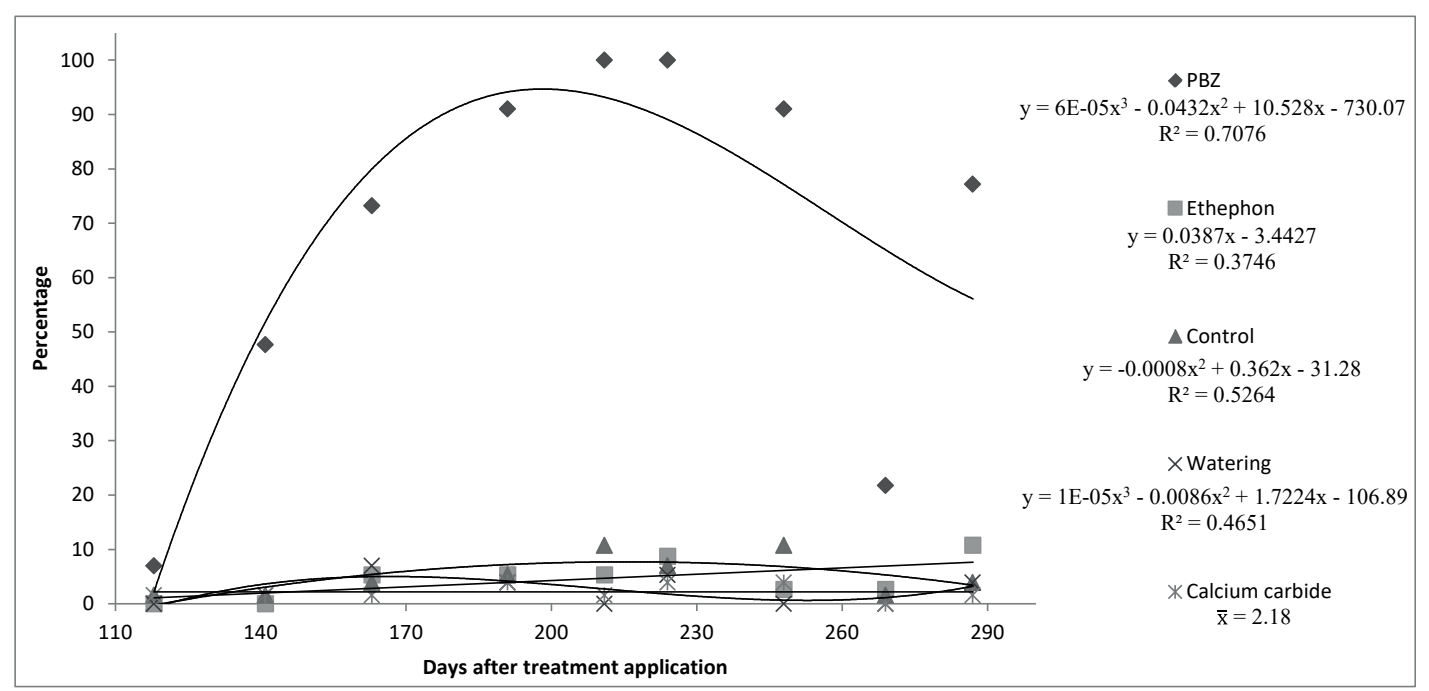

Figure 1. Percentage of jabuticaba trees with the presence of reproductive structures, according to the days after the treatment application (DAA) and flowering inducing treatment. 
Daily watering, empirically reported as a flowering-inductor for jabuticaba trees, did not show any effects, especially when compared to the paclobutrazol treatment (Figure 1), perhaps because young plants were used. This treatment should be evaluated in subsequent years.

Fruit production was inadequate, because it was the first productive cycle. However, the production occurred off-season, a period without fruit production in the native jabuticaba tree. The paclobutrazol treatment presented the shortest period between the application and the first reproductive structures arising, as well as a greater number of fruits produced (Table 3), with approximately sixty times more fruits per plant, in relation to the control. This effect is desirable for any crop, because it may reduce the time needed to achieve a productive cycle with greater fruit production.

A significant correlation was observed between epidermal detachment and trunk diameter and precipitation, as this behavior tends to occur in larger diameter trunk plants or in periods with higher precipitation (Table 5). The epidermal detachment is very common in Myrtaceae, but, in plants with a larger diameter, this phenomenon may be related to the renewal of this tissue due to lateral growth, and, for rainy periods, the stress caused by lower radiation makes the tissues to become more turgid, leading to detachment. Ethephon yielded the highest percentage of plants with epidermal detachment (Table 1), although it was not correlated to the flowering stimulus (Table 3 ).

As expected, the fruit production had a negative significant correlation with the growth variables (Table 5); therefore, lower diameter and height growth can provide favorable conditions for fruiting, since carbohydrates can be used for fruit production rather than vegetative growth (Kondhare et al. 2014, Upreti et al. 2014, Zhang et al. 2016).

Table 5. Pearson's correlation between plants in production (PP), epidermal detachment (ED), trunk diameter (TD), plant height $(\mathrm{PH})$, temperature $(\mathrm{T})$ and precipitation $(\mathrm{P})$.

\begin{tabular}{cccccc}
\hline & PP & TD & PH & T & P \\
\hline ED & $-0.2276^{\text {ns }}$ & $0.3878^{*}$ & $0.2601^{\text {ns }}$ & $-0.1565^{\text {ns }}$ & $0.3122^{*}$ \\
PP & & $-0.3407^{*}$ & $-0.3164^{*}$ & $-0.2158^{\text {ns }}$ & $0.1295^{\text {ns }}$ \\
TD & & & $0.2931^{*}$ & $0.1319^{\text {ns }}$ & $0.1135^{\text {ns }}$ \\
PH & & & & $0.5946^{*}$ & $-0.3695^{*}$ \\
T & & & & & $-0.5422^{*}$ \\
\hline
\end{tabular}

* Significant; ${ }^{\mathrm{ns}}$ non-significant $(\mathrm{p} \leq 0.05)$.
The trunk diameter and plant height had a positive significant correlation, but higher temperatures led to growth development, while precipitation had a negative influence. This is explained because higher precipitation levels result in lower temperatures within a given period.

There is a great potential to increase the commercial availability of the hybrid jabuticaba tree fruits, because the use of a paclobutrazol bioregulator to obtain fruiting off-season has been successful. By carrying out research and seeking to understand how to manage the cultivation of jabuticaba trees, the current scenario of this neglected species can be improved.

\section{CONCLUSIONS}

1. Paclobutrazol improves the reproductive period by increasing flowering and fruiting;

2. Ethephon induces a higher sprout growth and epidermal detachment, but has no effect on flowering;

3. Daily irrigation do not induce flowering in the hybrid jabuticaba tree.

\section{ACKNOWLEDGMENTS}

The authors thank the Universidade Tecnológica Federal do Paraná, Coordenação de Aperfeiçoamento de Pessoal de Nível Superior (Capes), Conselho Nacional de Desenvolvimento Científico e Tecnológico (CNPq) and Fundação Araucária.

\section{REFERENCES}

AKRAM, W. et al. Calcium carbide $\left(\mathrm{CaC}_{2}\right)$ : effect on fruit set and yield of mango (Mangifera indica L.) cv. Langra. African Journal of Biotechnology, v. 12, n. 23, p. 36693675, 2013.

ALMEIDA, G. M.; RODRIGUES, J. G. L. Desenvolvimento de plantas através da interferência de auxinas, citocininas, etileno e giberelinas. Brazilian Journal of Applied Technology for Agricultural Science, v. 9, n. 3, p. 111117, 2016.

AMARAL, L. F. G.; FIERRO, I. M. Profile of medicinal plants utilization through patent documents: the andiroba example. Brazilian Journal of Pharmacognosy, v. 23, n. 4, p. 716-722, 2013.

ATAIIDE, E. M. et al. Efeito do paclobutrazol e de ácido giberélico na indução floral do maracujazeiro-amarelo 
em condições de entressafra. Revista Brasileira de Fruticultura, v. 28, n. 2, p. 160-163, 2006.

BRESCASIN, R. L.; SOUZA-LEAL, T.; PEDROSODE-MORAES, C. Influência de diferentes substratos e concentrações de acetileno na floração de Catasetum fimbriatum (C. Morren) Lindl. e Paxton (Catasetinae, Orchidaceae). Revista Brasileira de Biociências, v. 11, n. 2, p. 191-196, 2013.

BURONDKAR, M. M. et al. Hormonal changes during flowering in response to paclobutrazol application in mango cv. Alphonso under Konkan conditions. Indian Journal of Plant Physiology, v. 21, n. 3, p. 306-311, 2016.

CARDOSO, M. G. S. et al. Florescimento e frutificação de mangueira (Mangifera indica L.) cv. Rosa promovidos por diferentes doses de paclobutrazol. Revista Brasileira de Fruticultura, v. 29, n. 2, p. 209-212, 2007.

CAVATTE, R. P. Q. et al. Redução do porte e produção das bananeiras Prata-Anã e Fhia-01 tratadas com paclobutrazol. Revista Brasileira de Fruticultura, v. 34, n. 2, p. 356-365, 2012.

COSTA, J. M. Modern viticulture in southern Europe: vulnerabilities and strategies for adaptation to water scarcity. Agricultural Water Management, v. 164, n. 1, p. 5-18, 2016.

CRUZ, M. C. M. et al. Florescimento de limeira ácida 'Tahiti' submetida a estresse hídrico e tratada com paclobutrazol. Cientifica, v. 37, n. 2, p. 53-60, 2009.

CUNHA, G. A. P. Applied aspects of pineapple flowering. Bragantia, v. 64, n. 4, p. 499-516, 2005.

DANNER, M. A. et al. Diagnóstico ecográfico da ocorrência de jabuticabeiras nativas no sudoeste do Paraná. Revista Brasileira de Fruticultura, v. 32, n. 3, p. 746-753, 2010.

FACTEAU, T. J.; CHESTNUT, N. E. Growth, fruiting, flowering, and fruit quality of sweet cherries treated with paclobutrazol. HortScience, v. 26, n. 3, p. 276-278, 1991.

FERNANDEZ-ESCOBAR, R. et al. The time of floral induction in the olive. Journal of the American Society of Horticultural Science, v. 117, n. 2, p. 304-307, 1992.

FRACARO, A. A.; PEREIRA, F. M. Efeito do ethephon sobre a brotação e vigor dos ramos da videira 'Niágara Rosada' (Vitis labrusca L.). Revista Brasileira de Fruticultura, v. 26, n. 3, p. 399-402, 2004.

FRANCO, L. R. L. et al. Pegamento e crescimento inicial de mudas de jabuticabeiras 'Açu' e 'Sabará' submetidas a dois tipos de enxertia. Revista Ceres, v. 57, n. 4, p. 535538, 2010.

KENDE, H.; ZEEVAART, J. The five "classical" plant hormones. The Plant Cell, v. 9, n. 7, p. 1197-1210, 1997.
KINUPP, V. F.; LISBÔA, G. N.; BARROS, I. B. I. Plinia peruviana jabuticaba. In: ESPÉCIES nativas da flora brasileira de valor econômico atual ou potencial: plantas para o futuro: região Sul. Brasília, DF: Ministério do Meio Ambiente, 2011. p. 198-204.

KIST, H. G. K. et al. Diquat e ureia no manejo da floração natural do abacaxizeiro 'Pérola'. Revista Brasileira de Fruticultura, v. 33, n. 4, p. 1048-1054, 2011.

KONDHARE, K. R. et al. Use of the hormonebiosynthesis inhibitors fluridone and paclobutrazol to determine the effects of altered abscisic acid and gibberellin levels on pre-maturity $\alpha$-amylase formation in wheat grains. Journal of Cereal Science, v. 60, n. 1, p. 210-216, 2014.

LAGE, F. F. et al. Jabuticaba [Plinia jaboticaba (Vell.) Berg] skins decrease lipid peroxidation: hepatoprotective and antihyperlipidemic effects. African Journal of Biotechnology, v. 13, n. 11, p. 1295-1302, 2014.

LEITE, G. H. P.; CRUSCIOL, C. A. C. Reguladores vegetais no desenvolvimento e produtividade da canade-açúcar. Pesquisa Agropecuária Brasileira, v. 43, n. 8, p. 995-1001, 2008.

LORENZI, H. et al. Frutas brasileiras e exóticas cultivadas. Nova Odessa: Instituto Plantarum de Estudos da Flora, 2006.

LUCENA, E. M. P. et al. Biodiversidade das Myrtaceae brasileiras adaptadas à Flórida, EUA. Revista Brasileira de Geografia Física, v. 7, n. 2, p. 327-340, 2014.

MALAGI, G. et al. Enxertia interespecífica de jabuticabeira: influência do tipo de garfo. Ciência Rural, v. 42, n. 2, p. 221-224, 2012.

MARUTHASALAN, S. et al. Forced flowering of pineapple (Ananas comosus cv. Tainon 17) in response to cold stress, ethephon and calcium carbide with or without activated charcoal. Plant Growth Regulator, v. 60, n. 1, p. 83-90, 2010.

MATTOS, J. R. Fruteiras nativas do Brasil: jabuticabeiras. Porto Alegre: Nobel, 1983.

MORAES, C. B. et al. Alterações morfológicas em Eucalyptus grandis sob aplicação de biorreguladores no período juvenil. Revista do Instituto Florestal, v. 24, n. 2, p. 251-257, 2012.

MORAES, C. B. et al. Variabilidade genética e alterações morfológicas em progênies de polinização aberta de Eucalyptus grandis sob o efeito de paclobutrazol. Científica, v. 42, n. 4, p. 369-403, 2014.

MOUCO, M. A. C.; ONO, E. O.; RODRIGUES, J. D. Inibidores de síntese da giberelinas e crescimento de mudas de mangueira 'Tommy Atkins'. Ciência Rural, v. 40, n. 2, p. 273-279, 2010. 
OLIVEIRA, A. F. et al. Paclobutrazol em oliveira submetida a diferentes regimes hídricos. Semina: Ciências Agrárias, v. 33, n. 6, p. 2137-2148, 2012.

RUFINO, M. S. M. et al. Bioactive compounds and antioxidant capacities of 18 non-traditional tropical fruits from Brazil. Food Chemistry, v. 121, n. 1, p. 996-1002, 2010.

SALLA, V. P. et al. Análise de trilha em caracteres de frutos de jabuticabeira. Pesquisa Agropecuária Brasileira, v. 50, n. 3, p. 218-223, 2015.

SCHMIDT, T. et al. Crop load overwhelms effects of gibberellic acid and ethephon on floral initiation in apple. HortScience, v. 44, n. 7, p. 1900-1906, 2009.

SILVA, J. A. L.; NEVES, J. A. Combinação do paclobutrazol, sulfato de potássio e etefon na indução floral da mangueira cv. Tommy Atkins. Comunicata Scientiae, v. 2, n. 1, p. 18-24, 2011.

SRIDHARAN, R.; RAJA, S.; SAKTHIVEL, P. Effect of triazole compounds on induced changes in growth biomass and biochemical content of white radish (Raphanus sativus L.). Journal of Plant Stress Physiology, v. 1, n. 1, p. 4348, 2015.

TAIZ, L.; ZEIGER, E. Fisiologia vegetal. 3. ed. Porto Alegre: Artmed, 2004.

UPRETI, K. K. et al. Paclobutrazol induced changes in carbohydrates and some associated enzymes during floral initiation in mango (Mangifera indica L.) cv. Totapuri. Indian Journal of Plant Physiology, v. 19, n. 4, p. 317323, 2014.

VERNIER, R. M.; CARDOSO, S. B. Influência do ácido indol-butírico no enraizamento de estacas em espécies frutíferas e ornamentais. Revista Eletrônica de Educação e Ciência, v. 3, n. 2, p. 11-16, 2013.

VIEIRA, V. L. L. P.; FERREIRA, W. R. A festa da jabuticaba e o empreendedorismo feminino no município de Sabará/MG. Revista Brasileira de Gestão e Engenharia, v. 8, n. 1, p. 1-28, 2013.

YESHITELA, T.; ROBBERTSE, P. J.; STASSEN, P. J. C. Paclobutrazol suppressed vegetative growth and improved yield as well as fruit quality of 'Tommy Atkins' mango (Mangifera indica) in Ethiopia. New Zealand Journal of Crop and Horticultural Science, v. 32, n. 1, p. 281-293, 2004.

ZHANG, S. et al. Effect of exogenous GA3 and its inhibitor paclobutrazol on floral formation, endogenous hormones, and flowering-associated genes in 'Fuji' apple (Malus domestica Borkh.). Plant Physiology and Biochemistry, v. 107, n. 1, p. 178-186, 2016.

ZONTA, E. P.; MACHADO, A. A. Sanest: sistema de análise estatística para microcomputadores. Pelotas: UFPel, 1984. 